\title{
Faktor sosiodemografi dan tinggi badan orang tua serta hubungannya dengan kejadian stunting pada balita usia 6-23 bulan
}

\author{
Sociodemographic and height of parents and its relationship with the incidence of stunting in \\ children aged 6-23 months
}

Nur Afia Amin', Madarina Julia²

\begin{abstract}
Background: Stunting is linear growth disturbance indicated by the value of the z-score of TB/U less than $-2 S D$. There are various factors associated with the incidence of stunting. Social demographics such as low income, low parental education and the number of members in the household, also indirectly related to the incidence of stunting. Parental height is also associated with the incidence of stunting. Short mothers have the possibility of having short baby. The results of the study in Egypt showed that children born from mothers with the height of $<150 \mathrm{~cm}$ have a higher risk to be stunted.

Objectives: To determine whether sociodemographic factors and parental height were risk factors for the incidence of stunting in children aged 6-23 months in Sedayu Subdistrict, Bantul, Yogyakarta.

Methods: The design used case-control study. The research was conducted in April-June 2014 in the Sedayu Subdistrict. Number of samples were 252 children aged 6-23 months. The instruments were a questionnaire to determine the identity of children, the identity of respondents, nutritional status, and sociodemographic data. Infantometer used to measure the length of the children body and microtoise to measure the height of parents. Bivariate analysis using chi-square and multivariate logistic regression test.

Result:s The prevalence of children stunting was $16.20 \%$. Bivariate test showed that the height of mothers significantly associated with the incidence of stunting. Multivariate analysis showed that the most influential factors to the was maternal height, while variables of employment, education, income, expenditure, number of family members, and height of father did not show significant results.

Conclusions: Maternal height were the risk factor for the incidence of stunting in children aged 6-23 months in Sedayu Subdistrict, but sociodemographic were not.
\end{abstract}

KEYWORDS: stunting, sociodemographic, parental height

\begin{abstract}
ABSTRAK
Latar belakang: Stunting merupakan gangguan pertumbuhan linier yang ditunjukkan dengan nilai skor-z TB/U kurang dari -2SD. Terdapat berbagai macam faktor yang berhubungan dengan kejadian stunting. Faktor sosial demografi, meliputi pendapatan yang rendah, pendidikan orang tua yang rendah, dan jumlah anggota dalam rumah tangga secara tidak langsung juga berhubungan dengan kejadian stunting. Tinggi badan orang tua juga berkaitan dengan kejadian stunting. Ibu yang pendek memiliki kemungkinan melahirkan bayi yang pendek pula. Hasil penelitian di Mesir menunjukkan bahwa anak yang lahir dari ibu dengan tinggi badan $<150 \mathrm{~cm}$ memiliki risiko lebih tinggi untuk tumbuh menjadi stunting.

Tujuan: Mengetahui faktor sosiodemografi dan tinggi badan orang tua sebagai faktor risiko kejadian stunting pada balita usia 6-23 bulan di Kecamatan Sedayu, Bantul, Yogyakarta.

Metode: Desain penelitian adalah case-control. Penelitian ini dilaksanakan pada bulan April-Juni 2014 di Kecamatan Sedayu. Besar sampel yang diambil sebesar 252 balita usia 6-23 bulan. Instrumen yang digunakan adalah kuesioner untuk mengetahui identitas balita, identitas responden, status gizi balita,
\end{abstract}

\footnotetext{
${ }^{1}$ Pasca Sarjana IImu Kesehatan Masyarakat Minat Gizi dan Kesehatan Fakultas Kedokteran Universitas Gadjah Mada, Jl. Farmako, Sekip Utara Yogyakarta 55281, e-mail: ning.afiah@gmail.com

2 Instalasi Kesehatan Anak RSUP Dr. Sardjito, e-mail: madarinajulia@yahoo.com
} 
dan data sosiodemografi. Infantometer digunakan untuk mengukur panjang badan balita dan microtoise untuk mengukur tinggi badan orang tua. Analisis bivariat menggunakan uji chi-square dan multivariat menggunakan uji regresi logistik.

Hasil : Dalam penelitian ini diketahui prevalensi kejadian stunting di Kecamatan Sedayu sebesar 16,20\%. Hasil uji bivariat menunjukkan bahwa variabel bebas yaitu tinggi badan ibu $(p=0,01)$ menunjukkan hubungan yang signifikan terhadap kejadian stunting. Hasil uji multivariat membuktikan bahwa variabel yang paling berpengaruh dengan stunting yaitu tinggi badan ibu. Variabel pekerjaan, pendidikan, pendapatan dan pengeluaran, jumlah anggota keluarga, dan tinggi badan ayah tidak menunjukkan hasil yang bermakna terhadap kejadian stunting.

Kesimpulan: Faktor sosioemografi bukan merupakan faktor risiko kejadian stunting, namun tinggi badan ibu merupakan faktor risiko kejadian stunting pada balita usia 6-23 bulan di Kecamatan Sedayu, Bantul, Yogyakarta.

KATA KUNCI : stunting, sosiodemografi, tinggi badan orang tua

\section{PENDAHULUAN}

Masa balita merupakan salah satu masa penting untuk kelangsungan hidup dan tumbuh kembang anak. Masa ini merupakan salah satu masa yang paling penting untuk meletakkan dasar-dasar kesehatan dan intelektual anak untuk kehidupan yang akan datang.

Indonesia, seperti negara berkembang lainnya memiliki beberapa masalah gizi pada balita di antaranya wasting, anemia, berat badan lahir rendah, dan stunting. Stunting merupakan kondisi kronis yang menggambarkan terhambatnya pertumbuhan karena malnutrisi jangka panjang. Stunting menurut WHO Child Growth Standard didasarkan pada indeks panjang badan menurut umur (PB/U) atau tinggi badan menurut umur (TB/U) dengan batas (z-score) <-2 SD (1).

Prevalensi stunting tertinggi terjadi pada anak saat berusia 24-59 bulan (2). Proses menjadi pendek atau stunting pada anak di suatu wilayah atau daerah miskin dimulai sejak usia sekitar 6 bulan dan muncul utamanya pada dua sampai tiga tahun awal kehidupan serta berlangsung terus sampai usia 18 tahun (3). Stunting yang terjadi dalam usia 36 bulan pertama biasanya disertai dengan efek jangka panjang (4).

Kasus kejadian stunting mengindikasikan masalah kesehatan masyarakat karena berhubungan dengan meningkatnya risiko morbiditas dan mortalitas, terhambatnya perkembangan dan fungsi motorik dan mental serta mengurangi kapasitas fisik. Anak dengan keadaan stunting tidak mengalami potensi pertumbuhan secara maksimal dan dapat menjadi remaja dan dewasa yang stunting (5).

Ada berbagai macam faktor yang berhubungan dengan kejadian stunting. Faktor sosial demografi meliputi pendapatan yang rendah, pendidikan orang tua yang rendah, jumlah anggota keluarga, dan faktor ekonomi dalam rumah tangga secara tidak langsung juga berhubungan dengan kejadian stunting $(1,6,7)$. Pendapatan akan mempengaruhi pemenuhan zat gizi keluarga dan kesempatan dalam mengikuti pendidikan formal. Rendahnya pendidikan disertai rendahnya pengetahuan gizi sering dihubungkan dengan kejadian malnutrisi (8).

Tinggi badan orang tua juga berkaitan dengan kejadian stunting. Ibu yang pendek memiliki kemungkinan melahirkan bayi yang pendek pula. Hasil penelitian di Mesir menunjukkan bahwa anak yang lahir dari ibu yang memiliki tinggi badan $<150$ $\mathrm{cm}$ memiliki risiko lebih tinggi untuk tumbuh menjadi stunting (9).

Prevalensi stunting secara nasional tahun 2013 sebesar $37,2 \%$, yang berarti terjadi peningkatan dibanding tahun 2010, dengan prevalensi sebesar $35,6 \%$. Prevalensi stunting sebesar $37,2 \%$ terdiri dari $18,0 \%$ sangat pendek dan $19,2 \%$ pendek. Bila dibandingkan dengan prevalensi sangat pendek dan pendek tahun 2010 terlihat ada sedikit penurunan pada prevalensi sangat pendek dari $18,5 \%$ tahun 2010 menjadi $18,0 \%$ tahun 2013 dan prevalensi pendek meningkat dari $17,1 \%$ tahun 2010 menjadi 19,2\% tahun 2013 (10). 
Hasil pemantauan status gizi tahun 2012 yang dilakukan oleh Dinas Kesehatan Kabupaten Bantul diperoleh hasil bahwa di Kabupaten Bantul masih belum bebas dari masalah kesehatan. Hal tersebut disebabkan masih ada kasus balita stunting dengan prevalensi $18,08 \%$ yang terdiri dari prevalensi sangat pendek $4,46 \%$ dan prevalensi pendek $13,45 \%$. Di Kecamatan Sedayu juga masih ditemukan kasus stunting sebesar $16,93 \%$.

\section{BAHAN DAN METODE}

Jenis penelitian yang digunakan dalam penelitian ini adalah observasional dengan menggunakan rancangan case-control yang dilaksanakan di Kecamatan Sedayu, Bantul, Yogyakarta. Penelitian ini merupakan bagian dari penelitian yang berjudul "Status Gizi lbu Hamil dan Baduta di Kecamatan Sedayu Kabupaten Bantul D.I Yogyakarta" yang dilaksanakan oleh Alma Ata Center For Healthy Life and Food (ACHEAF) Yogyakarta. Besar sampel penelitian dihitung menggunakan rumus uji hipotesis perbedaan 2 proporsi. Jumlah total baduta skrining yaitu 852 baduta dan yang memenuhi standar stunting yaitu 138 baduta. Saat pengambilan data, 12 subjek stunting tidak diambil karena tidak memenuhi kriteria inklusi dan sebagian orang tuanya bekerja di luar daerah sehingga sulit melakukan pengukuran tinggi badan orang tua. Dengan demikian, total baduta kasus dan kontrol masing-masing sebanyak 126, sehingga total keseluruhan sampel yaitu 252 baduta. Adapun pelaksanaan penelitian dimulai bulan April hingga Juni tahun 2014.

Variabel bebas bebas dalam penelitian ini adalah faktor sosiodemografi (pendapatan, pendidikan orang tua, dan jumlah anggota keluarga) serta tinggi badan orang tua, sementara variabel terikat adalah kejadian stunting. Subjek penelitian adalah balita usia 6-23 bulan yang memenuhi kriteria inklusi dan eksklusi. Kriteria inklusi kasus adalah ibu yang mempunyai balita stunting usia 6-23 bulan, dan yang memiliki balita tidak stunting usia 6-23 bulan untuk kontrol, bertempat tinggal tetap di Kecamatan Sedayu, orang tua atau wali anak mengizinkan anak untuk menjadi sampel penelitian selama penelitian berlangsung sekaligus bersedia menjadi responden dengan menandatangani informed consent. Apabila sebuah keluarga memiliki anak usia 6-23 bulan lebih dari satu orang maka anak yang dijadikan sampel penelitian adalah anak yang lebih tua dan anak dalam keadaan sehat. Kriteria eksklusi kasus dan kontrol adalah anak menderita menderita penyakit kongenital atau cacat fisik, anak yang sedang mengalami pemulihan dari status gizi buruk, ibu atau ayah kandung telah meninggal dunia, anak tidak tinggal bersama orang tua atau tempat tinggal orang tuanya sulit dijangkau. Instrumen yang digunakan yaitu kuesioner untuk mengetahui karakteristik keluarga subjek penelitian dan wawancara mengenai faktor sosiodemografi dengan kejadian stunting balita. Microtoise digunakan untuk mengukur tinggi badan orang tua subjek penelitian dan infantometer digunakan untuk mengukur panjang badan anak, masing-masing anak memiliki ketelitian $0,1 \mathrm{~cm}$. Penelitian ini telah mendapat persetujuan dari Komisi Etik Penelitian Kedokteran dan Kesehatan Fakultas Kedokteran Universitas Gadjah Mada nomor Ref: KE/FK/382/EC tahun 2014.

\section{HASIL}

Hasil analisis bivariat variabel bebas (pendidikan orang tua, pekerjaan orang tua, pendapatan, dan jumlah anggota keluarga) terhadap kejadian stunting menunjukkan bahwa tidak ada satupun variabel sosiodemografi yang bermakna terhadap kejadian stunting (Tabel 1).

Hasil uji bivariat ini menunjukkan bahwa pekerjaan ayah tidak memiliki nilai yang signifikan. Hasil analisis bivariat menunjukkan bahwa variabel bebas tinggi badan ibu berhubungan dengan kejadian stunting ( $p=0,01,95 \% \mathrm{Cl}: 1,14-3,65)$. Tinggi badan ayah diketahui tidak memiliki nilai yang signifikan dengan kejadian stunting dengan nilai ( $p=0,29,95 \% \mathrm{Cl}$ : 0,76-2,33).

Pada Tabel 2 menunjukkan bahwa berat badan lahir merupakan faktor risiko kejadian stunting dengan nilai $p$ sebesar 0,03 dan nilai OR sebesar 3,03 . Hal ini berarti anak yang lahir dengan berat badan <2.500 gram akan berpeluang 
Tabel 1. Tabulasi silang variabel bebas dengan stunting

\begin{tabular}{|c|c|c|c|c|c|c|c|}
\hline \multirow[t]{2}{*}{ Variabel } & \multicolumn{2}{|c|}{$\begin{array}{c}\text { Stunting } \\
\text { (Kasus) }\end{array}$} & \multicolumn{2}{|c|}{$\begin{array}{c}\text { Tidak stunting } \\
\text { (Kontrol) }\end{array}$} & \multirow[t]{2}{*}{ OR } & \multirow[t]{2}{*}{$95 \% \mathrm{Cl}$} & \multirow[t]{2}{*}{$\mathbf{p}$} \\
\hline & $\mathbf{n}$ & $\%$ & $\mathbf{n}$ & $\%$ & & & \\
\hline \multicolumn{8}{|l|}{ Pendidikan ayah } \\
\hline Rendah & 43 & 34,13 & 46 & 36,51 & 0,90 & $0,52-1,56$ & 0,69 \\
\hline Tinggi & 83 & 65,87 & 80 & 63,49 & & & \\
\hline \multicolumn{8}{|l|}{ Pendidikan ibu } \\
\hline Rendah & 42 & 33,33 & 46 & 36,51 & 0,87 & $0,50-1,51$ & 0,50 \\
\hline Tinggi & 84 & 66,67 & 80 & 63,49 & & & \\
\hline \multicolumn{8}{|l|}{ Pekerjaan ayah } \\
\hline Tidak tetap & 86 & 68,25 & 75 & 59,52 & 1,46 & $0,84-2,54$ & 0,15 \\
\hline Tetap & 40 & 31,75 & 51 & 40,48 & & & \\
\hline \multicolumn{8}{|l|}{ Pekerjaan ibu } \\
\hline Tidak tetap & 106 & 84,13 & 101 & 80,16 & 1,31 & $0,65-2,66$ & 0,41 \\
\hline Tetap & 20 & 15,87 & 25 & 19,84 & & & \\
\hline \multicolumn{8}{|l|}{ Pendapatan } \\
\hline Kuartil 1 & 27 & 21,43 & 21 & 16,67 & 1,90 & $0,88-4,14$ & 0,09 \\
\hline Kuartil 2 & 19 & 15,08 & 18 & 14,29 & 1,56 & $0,68-3,58$ & 0,29 \\
\hline Kuartil 3 & 35 & 27,78 & 27 & 21,43 & 1,92 & $0,93-3,97$ & 0,07 \\
\hline Kuartil 4 & 20 & 15,87 & 23 & 18,25 & 1,29 & $0,58-2,84$ & 0,53 \\
\hline Kuartil 5 & 25 & 19,84 & 37 & 29,37 & Ref & Ref & Ref \\
\hline \multicolumn{8}{|c|}{ Jumlah anggota keluarga } \\
\hline$>4$ orang & 71 & 56,35 & 66 & 52,38 & 1,17 & $0,69-1,99$ & 0,53 \\
\hline$\leq 4$ orang & 55 & 43,65 & 60 & 47,62 & & & \\
\hline \multicolumn{8}{|l|}{ Tinggi badan ayah } \\
\hline Kurang & 46 & 36,51 & 38 & 30,16 & 1,33 & $0,76-2,33$ & 0,29 \\
\hline Normal & 80 & 63,49 & 88 & 69,84 & & & \\
\hline \multicolumn{8}{|l|}{ Tinggi badan ibu } \\
\hline Kurang & 49 & 38,89 & 30 & 23,81 & 2,04 & $1,14-3,65$ & $0,01^{*}$ \\
\hline Normal & 77 & 61,11 & 96 & 76,19 & & & \\
\hline
\end{tabular}

*Signifikan $(p<0,05)$

Tabel 2. Tabulasi silang variabel luar dengan stunting

\begin{tabular}{|c|c|c|c|c|c|c|c|}
\hline \multirow[t]{2}{*}{ Variabel } & \multirow{2}{*}{$\begin{array}{c}\begin{array}{c}\text { Stunting } \\
\text { (Kasus) }\end{array} \\
\mathbf{n} \\
\end{array}$} & \multicolumn{3}{|c|}{$\begin{array}{l}\text { Tidak stunting } \\
\text { (Kontrol) }\end{array}$} & \multirow[t]{2}{*}{ OR } & \multirow[t]{2}{*}{$95 \% \mathrm{Cl}$} & \multirow[t]{2}{*}{$\mathbf{p}$} \\
\hline & & $\%$ & $\mathbf{n}$ & $\%$ & & & \\
\hline \multicolumn{8}{|l|}{ Berat badan lahir } \\
\hline $\begin{array}{l}\text { BBLR } \\
\text { BBLN }\end{array}$ & $\begin{array}{c}14 \\
112\end{array}$ & $\begin{array}{l}11,11 \\
88,89\end{array}$ & $\begin{array}{c}5 \\
121\end{array}$ & $\begin{array}{c}3,97 \\
96,03\end{array}$ & 3,03 & $0,99-11,04$ & 0,03 \\
\hline \multicolumn{8}{|l|}{ Jenis kelamin } \\
\hline $\begin{array}{l}\text { Laki-laki } \\
\text { Perempuan }\end{array}$ & $\begin{array}{l}66 \\
60\end{array}$ & $\begin{array}{l}52,38 \\
47,62\end{array}$ & $\begin{array}{l}74 \\
52\end{array}$ & $\begin{array}{l}58,73 \\
41,27\end{array}$ & 0,77 & $0,46-1,31$ & 0,31 \\
\hline \multicolumn{8}{|c|}{ Riwayat penyakit infeksi } \\
\hline $\begin{array}{l}\text { Infeksi } \\
\text { Tidak infeksi }\end{array}$ & $\begin{array}{l}78 \\
48\end{array}$ & $\begin{array}{l}61,90 \\
38,10\end{array}$ & $\begin{array}{l}75 \\
51\end{array}$ & $\begin{array}{l}59,52 \\
40,48\end{array}$ & 1,11 & $0,65-1,89$ & 0,69 \\
\hline \multicolumn{8}{|c|}{ Pengeluaran rumah tangga } \\
\hline Kuartil 1 & 30 & 23,81 & 20 & 15,87 & 2,67 & $1,15-6,16$ & 0,02 \\
\hline Kuartil 2 & 24 & 19,05 & 27 & 21,43 & 1,58 & $0,71-3,54$ & 0,26 \\
\hline Kuartil 3 & 27 & 21,43 & 23 & 18,25 & 2,09 & $0,92-4,74$ & 0,07 \\
\hline Kuartil 4 & 27 & 21,43 & 24 & 19,05 & 2,00 & $0,89-4,51$ & 0,09 \\
\hline Kuartil 5 & 18 & 14,29 & 32 & 25,40 & Ref & Ref & Ref \\
\hline
\end{tabular}


stunting sebesar 3,03 kali lebih besar dibandingkan anak yang lahir dengan berat badan normal. Jenis kelamin dan penyakit infeksi diketahui tidak memiliki hasil yang bermakna terhadap kejadian stunting $(p>0,05)$. Nilai pengeluaran pada kuartil 1 menunjukkan hubungan yang bermakna dengan nilai $p=0,02$ yang artinya bahwa rumah tangga yang pengeluaran rumah tangganya kurang dari $R p$ 937.704 akan berisiko 2,67 kali lebih besar memiliki anak yang stunting dibanding kelompok rumah tangga yang pengeluaran rumah tangganya lebih dari Rp 937.704.

Pada analisis multivariat (Tabel 3 ) analisis regresi model 1 menunjukkan bahwa tinggi badan ibu mempunyai nilai yang bermakna terhadap kejadian stunting dengan nilai $\mathrm{OR}=1,98$. Hal ini berarti bahwa ibu yang pendek akan berisiko melahirkan anak yang stunting 1,98 kali lebih besar dibandingkan ibu dengan tinggi badan yang normal.

Analisis regresi logistik model 2 untuk mengetahui kemaknaan hubungan antara variabel sosiodemografi dan tinggi badan orang tua dengan kejadian stunting serta besarnya pengaruh variabel berat badan lahir. Model 2 menunjukkan $\mathrm{R}^{2}$ mengalami peningkatan sebesar 0,01 menjadi 0,04 yang artinya seluruh variabel bebas dapat memprediksi kejadian stunting sebesar $4 \%$.

Analisis regresi logistik model 3 untuk mengetahui kemaknaan hubungan antara semua variabel bebas dengan kejadian stunting serta besarnya pengaruh variabel pengeluaran sebagai variabel luar yang diikutsertakan dalam analisis. Model 3 menunjukkan $\mathrm{R}^{2}$ sebesar 0,04 yang artinya semua variabel bebas setelah dikontrol dengan pengeluaran dapat memprediksi kejadian stunting sebesar $4 \%$.

Analisis regresi logistik model 4 untuk mengetahui kemaknaan hubungan antara variabel bebas dengan mengikut sertakan semua variabel luar yang bermakna yaitu riwayat BBLR dan pengeluaran. Model 4 ini menunjukkan nilai $R^{2}$ sebesar 0,05 yang artinya bahwa faktor sosiodemografi dan tinggi badan orang tua setelah dikontrol dengan riwayat BBLR dan pengeluaran, dapat memprediksi kejadian stunting sebesar $5 \%$. Pada analisis model 4 ini, variabel yang paling mempengaruhi stunting adalah tinggi badan ibu dengan nilai $O R=1,87$, sedangkan variabel lain tidak memiliki nilai yang bermakna setelah dikontrol dengan riwayat BBLR dan pengeluaran rumah tangga.

\section{BAHASAN}

Stunting atau pendek, merupakan suatu retardasi pertumbuhan linear yang digunakan secara luas untuk mengukur status gizi individu ataupun kelompok. Berdasarkan hasil penelitian

Tabel 3. Analisis multivariat faktor-faktor yang berhubungan dengan stunting

\begin{tabular}{|c|c|c|c|c|}
\hline Variabel & $\begin{array}{c}\text { Model } 1 \\
\text { OR } \\
(95 \% \mathrm{Cl}) \\
\end{array}$ & $\begin{array}{c}\text { Model } 2 \\
\text { OR } \\
(95 \% \mathrm{Cl}) \\
\end{array}$ & $\begin{array}{c}\text { Model } 3 \\
\text { OR } \\
(95 \% \mathrm{Cl}) \\
\end{array}$ & $\begin{array}{c}\text { Model } 4 \\
\text { OR } \\
(95 \% \mathrm{Cl}) \\
\end{array}$ \\
\hline Pekerjaan ayah & $\begin{array}{c}1,32 \\
(0,77-2,26)\end{array}$ & $\begin{array}{c}1,30 \\
(0,76-2,25)\end{array}$ & $\begin{array}{c}1,31 \\
(0,76-2,25)\end{array}$ & $\begin{array}{c}1,29 \\
(0,74-2,22)\end{array}$ \\
\hline Pendapatan & $\begin{array}{c}1,46 \\
(0,79-2,67)\end{array}$ & $\begin{array}{c}1,48 \\
(0,80-2,74)\end{array}$ & $\begin{array}{c}1,25 \\
(0,66-2,39)\end{array}$ & $\begin{array}{c}1,27 \\
(0,66-2,42)\end{array}$ \\
\hline Tinggi badan ayah & $\begin{array}{c}1,26 \\
(0,74-2,16)\end{array}$ & $\begin{array}{c}1,32 \\
(0,77-2,27)\end{array}$ & $\begin{array}{c}1,21 \\
(0,70-2,08)\end{array}$ & $\begin{array}{c}1,26 \\
(0,73-2,18)\end{array}$ \\
\hline Tinggi badan ibu & $\begin{array}{c}1,98 \\
(1,14-3,43)\end{array}$ & $\begin{array}{c}1,92 \\
(1,10-3,35)\end{array}$ & $\begin{array}{c}1,93 \\
(1,11-3,35)\end{array}$ & $\begin{array}{c}1,87 \\
(1,07-3,26)\end{array}$ \\
\hline Riwayat BBLR & & $\begin{array}{c}3,02 \\
(1,03-8,85)\end{array}$ & & $\begin{array}{c}3,14 \\
(1,07-9,24)\end{array}$ \\
\hline Pengeluaran & & & $\begin{array}{c}1,65 \\
(0,82-3,31)\end{array}$ & $\begin{array}{c}1,73 \\
(0,85-3,51)\end{array}$ \\
\hline $\mathrm{R}^{2}(\%)$ & 0,03 & 0,04 & 0,04 & 0,05 \\
\hline$N$ & 252 & 252 & 252 & 252 \\
\hline
\end{tabular}

* Signifikan $(p<0,05)$ 
diketahui bahwa prevalensi kejadian stunting pada balita usia 6-23 bulan di Kecamatan Sedayu sebesar $16,20 \%$.

Berdasarkan Tabel 1, diketahui bahwa dari keseluruhan total responden, balita stunting lebih banyak ditemukan pada kelompok laki-laki $(52,38)$ daripada perempuan $(47,62)$. Hasil ini sejalan dengan penelitian di Maluku tahun 2004 yang menyatakan bahwa anak perempuan memiliki pacu tumbuh yang lebih cepat dibanding anak laki-laki (2). Namun demikian, hasil penelitian ini berbeda dengan penelitian yang dilakukan di Semarang Timur yang menunjukkan bahwa perempuan lebih berisiko terkena stunting dibanding laki-laki (8), juga penelitian yang dilakukan di daerah pedesaan Pakistan yang hasil penelitiannya menunjukkan bahwa anak usia sekolah lebih berisiko stunting pada anak perempuan $(18,3 \%)$ dibanding laki-laki $(14,6 \%)(11)$.

\section{Hubungan pendidikan orang tua dengan kejadian stunting}

Hasil uji bivariat (Tabel 1) penelitian ini menunjukkan bahwa pendidikan ayah tidak memiliki hubungan yang bermakna dengan kejadian stunting $(p>0,05)$. Begitu pula dengan pendidikan ibu, tidak menunjukkan hasil yang bermakna terhadap kejadian stunting $(p>0,05)$.

Pendidikan ayah dan pendidikan ibu merupakan faktor prediktor yang paling kuat terhadap terjadinya stunting pada anak balita (12). Tingkat pendidikan ibu dengan perkembangan mental anak batita gizi kurang memiliki hubungan yang bermakna (13). Pendidikan ibu berpengaruh terhadap tingginya angka kejadian stunting (14). Pendidikan formal ibu memiliki pengaruh terhadap jangka panjang status gizi anak melalui informasi nutrisi di Jawa Tengah (15).

Tidak ditemukannya hubungan yang signifikan antara pendidikan ayah dan ibu terhadap kejadian stunting di Kecamatan Sedayu menunjukkan bahwa di daerah tersebut, akses terhadap pendidikan dan sarana sebagai penunjang informasi masih terbilang mudah. Ini terlihat pada Tabel 1 dimana pendidikan ayah dan ibu terbilang tinggi, artinya mereka menamatkan sekolahnya sampai jenjang SMA.

\section{Hubungan pekerjaan orang tua dengan kejadian stunting}

Hasil analisis bivariat pada Tabel 1 menunjukkan bahwa tidak ada hubungan yang bermakna antara pekerjaan ayah terhadap kejadian stunting. Hasil penelitian ini menunjukkan bahwa sebagian besar orang tua responden adalah pekerja tidak tetap, yaitu sebagai buruh. Hal ini berpengaruh pada sedikitnya pendapatan yang masuk. Rendahnya pendapatan menyebabkan kurang terpenuhinya asupan zat gizi dan dapat menyebabkan stunting.

\section{Hubungan pendapatan keluarga dengan kejadian stunting}

Faktor pendapatan memiliki peranan besar dalam persoalan gizi dan kebiasaan makan keluarga terutama tergantung kemampuan keluarga untuk membeli pangan yang dibutuhkan keluarga tersebut (16). Anak-anak yang berasal dari keluarga yang miskin bersinergi dengan kekurangan gizi yaitu stunting (17).

Hasil penelitian ini menunjukkan bahwa tidak ada hubungan yang bermakna antara pendapatan keluarga dengan kejadian stunting $(p>0,05)$. Hal ini dapat terjadi karena kemampuan keluarga untuk membeli bahan makanan tidak hanya bergantung pada besar kecilnya pendapatan keluarga, namun juga harga bahan makanan itu sendiri dan tingkat pengelolaan sumber daya lahan pekarangan. Rumah tangga di Kecamatan Sedayu sebagian besar memiliki pekarangan sehingga dapat memenuhi kebutuhan pangan.

\section{Hubungan jumlah anggota keluarga dengan kejadian stunting}

Jumlah anggota keluarga yang bertambah menyebabkan pangan untuk setiap anak menjadi berkurang dan distribusi makanan tidak merata sehingga menyebabkan balita dalam keluarga tersebut kurang gizi (18). Hasil penelitian ini menunjukkan nilai yang berbeda, di mana tidak ada hubungan yang bermakna antara jumlah anggota keluarga dengan kejadian stunting $(p>0,05)$. Hal ini bisa disebabkan oleh faktor lain yang lebih signifikan 
yang tidak diteliti seperti pengetahuan ibu terhadap penyediaan makan di rumah.

Umumnya, keluarga dengan anggota yang banyak akan menghabiskan lebih banyak biaya untuk memenuhi kebutuhan juga akan adanya persaingan atau keterbatasan dalam menyediakan makanan yang bergizi seimbang.

\section{Hubungan tinggi badan orang tua dengan kejadian stunting}

Hasil analisis bivariat dan multivariat menunjukkan bahwa anak yang dilahirkan oleh ibu yang pendek memperbesar peluang anak tumbuh menjadi stunting. Tinggi badan ibu merupakan salah satu faktor yang berhubungan dengan tinggi badan anak $(19,20)$. Penelitian di Mesir menunjukkan bahwa anak yang lahir dari ibu dengan tinggi badan kurang dari $150 \mathrm{~cm}$ lebih berisiko untuk tumbuh stunting. Akan tetapi banyak hal yang mempengaruhi kejadian stunting utamanya interaksi antara genetik dan faktor lingkungan (9).

\section{Variabel luar penyebab stunting}

Selain faktor-faktor di atas, stunting dapat disebabkan oleh beberapa hal berikut. Apabila balita tidak memiliki imunitas terhadap penyakit, maka balita akan lebih cepat kehilangan energi tubuh karena penyakit infeksi, sebagai reaksi pertama akibat adanya infeksi adalah menurunnya nafsu makan anak sehingga anak menolak makanan yang diberikan ibunya. Penolakan terhadap makanan berarti berkurangnya pemasukan zat gizi dalam tubuh anak (21).

Selain itu, masalah BBLR tidak terlepas dari salah satu faktor penyebab masalah stunting. Anak yang terlahir BBLR berisiko untuk menjadi . BBLR masih tetap menjadi masalah dunia khususnya di negara-negara berkembang (22).

Pengeluaran keluarga baik makanan maupun non makanan dapat dijadikan sebagai gambaran tingkat pendapatan keluarga. Pengeluaran keluarga dapat mempengaruhi konsumsi pangan keluarga, dapat menentukan pola makan dan juga menentukan kualitas dan kuantitas hidangan (23).

\section{KESIMPULAN DAN SARAN}

Pendidikan ayah dan ibu, pekerjaan ayah dan ibu, pendapatan keluarga, dan jumlah anggota keluarga bukan merupakan faktor risiko kejadian stunting pada balita usia 6-23 bulan di Kecamatan Sedayu. Tinggi badan ayah bukan merupakan faktor risiko namun tinggi badan ibu merupakan faktor risiko kejadian stunting pada anak usia 6-23 bulan di Kecamatan Sedayu.

Perlu diadakannya edukasi kesehatan untuk semua wanita usia subur agar di masa depan dapat lebih memahami mengenai pentingnya menjaga status gizi pada masa sebelum/masa remaja sampai kehamilan agar melahirkan bayi yang sehat. Selain itu pentingnya pemahaman akan ASI eksklusif sejak lahir sampai berusia 6 bulan dan terus diberikan sampai usia 24 bulan agar anak yang lahir tidak berisiko stunting. Penanaman pemahaman melalui kader kepada ibu balita bahwa balita yang terindikasi stunting di bawah 2 tahun dapat dikejar pertumbuhannya dengan memberikan asupan gizi yang seimbang sesuai yang dibutuhkan usianya. Perlu diadakannya penelitian lanjutan, bukan hanya di Kecamatan Sedayu sehingga mendapatkan gambaran yang lebih terperinci mengenai faktorfaktor penyebab stunting di Kabupaten Bantul.

\section{RUJUKAN}

1. World Health Organization (WHO). Child malnutrition: children aged $<5$ years stunted by country. 2010.

2. Ramli, Agho K, Inder K, Bowe S, Jacobs J, Dibley M. Prevalence and risk factors for stunting and severe stunting among under-fives in North Maluku Province of Indonesia. Biomed Cent Pediatr. 2009;9(64):1471-2431.

3. Sudiman H. Stunting atau pendek: Awal perubahan patologis atau adaptasi karena perubahan sosial ekonomi yang berkepanjangan. Media Litbang Kesehat. 2008;18(1):33-42.

4. Gibney M, Margaretts B, Kearney J, Arab L. Pengantar gizi masyarakat. Jakarta: Penerbit Buku Kedokteran EGC. 
5. Ricci J, Becker S. Risk faktor for wasting and sunting among children in Metro Cebu, Philippines. Am J Clin Nutr. 1996;63:966-75.

6. Musthaq M, Gull, Kurshid, Shahid, Siddiqui A. Prevalence and socio-demographic correlates of stunting and thinness among Pakistani primary school children. BMC Public Health. 2011;11:790.

7. Pongou R, Ezzati M, Salomon J. Household and community socioeconomic and environmental determinants of child nutritional status in Cameroon. BMC Public Health. 2006;6(98):1471-2458.

8. Nashikhah R. Faktor risiko kejadian stunting pada balita usia 24-36 bulan di Kecamatan Semarang Timur. J Nutr Coll. 2012;1(1):17684.

9. Zottarelli L, Sunil T, Rajaram S. Influence of parental and socioeconomic factors on stunting in hildren under 5 years in Egypt. East Mediterr Heal J. 2007;13(6):1330-42.

10. Kementerian Kesehatan Republik Indonesia. Hasil riset kesehatan dasar. Jakarta: Badan Litbangkes Rl; 2013.

11. Khuwaja S, Beatrice J, Syed M. Prevalence and correlates of stunting among primary school children in Rural Areas of Southern Pakistan. J Trop Pediatr. 2005;5(2).

12. Biswas $\mathrm{S}$, Bose K. Sex differences in the effect of birth order and parents education status on stunting : a study on Bengalee preschool children from Eastern India. HOMO-Journal Comp Hum Biol. 2010;61:271-6.

13. Mulyati S. Penelitian gizi dan makanan. Bogor: Puslitbang Gizi; 1990.
14. Thomas D, John S, Helena M. How does mother's education affect child height. J Hum Resour. 1991;26(2):183-211.

15. Webb P, Block S. Nutrition Information and Formal Schooling as Inputs to Child Nutrition Economic Development and Cultural Change. J Nutr. 2004;52(4):801-20.

16. Azwar. Masalah gizi kurang pada balita dan upaya penanggulangan di Indonesia. Bogor; 2000.

17. Mendez M, Adair L. Severity and timing of stunting in the first two years of life affect performance on cognitive tests in late childhood. J Nutr. 1999;129:1555-62.

18. Chaudhury R. Determinants of dietary intake and dietary adequacy for pre-school children in Bangladesh. Bangladesh Institute of Development Studies. 2012.

19. Adair L, Guilkey D. Age-specific determinan of stunting in Filipino children. J Nutr. 1997;127:31420.

20. Dangour A, Hill H, Ismail S. Height, weight and haemoglobin status of 6 to 59 month old Kazakh children living in Kzyl-Orda region, Kazakhstan. Eur J Clin Nutr. 2002;6:1030-8.

21. Akre J. Pemberian makanan untuk bayi, dasardasar fisiologis. Jakarta: FKM UI; 1994.

22. Kawai K, Donna S, Anuraj H, Shankar, Wafaie. Maternal multiple micronutrient supplementation and pregnancy outcomes in developing countries: meta-analysis and meta-regression. Bull World Health Organ. 2011;89(6):393-468.

23. Bonnie, Worthington $R$, Sue R. Nutrition Throughout the Life Cycle Fourth Edition. New York: Mc. Graw Hills Higher Education; 2000. 